\title{
Rencana Pengembangan Jenjang Karir Perawat Klinis Di Rumah Sakit Umum Daerah (RSUD) Kota Dumai
}

\author{
Muhammad Rizul Efendi*1, Elfindri², Jasrida Yunita ${ }^{2}$ \\ ${ }^{1}$ Program Studi Magister Kesehatan Masyarakat \\ ${ }^{2}$ STIKes Hang Tuah Pekanbaru \\ *Correspondence Email : $\underline{\text { mr.ef18@gmail.com }}$
}

\begin{abstract}
Professional nurse career development in the form of career paths is a system to improve performance and professionalism, in accordance with the field of work through enhancing competencies that produce professional performance. The aim of this research was to find out the development plan for clinical nurse careers at Dumai Regional General Hospital. The research used is qualitative method. This research was conducted in August 2018. Data analysis was carried out in the form of data appearance, data verification, and matrix formation. The informants in this study amounted to 16 people who were taken based on purposive sampling. The research results obtained important themes namely; Human Resources (HR), Costs and Internship Processes are still a problem in efforts to develop clinical nurse careers.The research results obtained important themes namely; the comparison of the number of clinical assessors and nurses is not ideal, there are regulations about the number of clinical nurses who can participate in the credential process, many clinical nurses who work not according to their competence due to the impact of the length of credential process waiting time, lack of motivation of clinical nurses in following the credential process, not yet the issuance of the prescription decree, the absence of incentives for the preceptor, the lack of formulation of an increase in career level services, and the Internship process not yet implemented in the credential process.
\end{abstract}

Keyword : Career, Clinical Nurse

\begin{abstract}
Abstrak
Pengembangan karir professional perawat dalam bentuk jenjang karir merupakan sistem untuk meningkatkan kinerja dan profesionalisme, sesuai dengan bidang pekerjaan melalui peningkatan kompetensi yang menghasilkan kinerja profesional.Tujuan penelitian ini ialah diketahuinya rencana pengembanganjenjang karir perawat klinis di Rumah Sakit Umum Daerah (RSUD) Kota Dumai. Penelitian yang digunakan ialah metode kualitatif. Penelitian ini dilaksanakan pada bulan Agustus Tahun 2018.Analisa data dilakukan berupa penampilan data, veirfikasi data, dan pembentukan matriks. Informan dalam penelitian ini berjumlah 16 orang yang diambil berdasarkan purposive sampling. Hasil penelitian diperoleh tema-tema penting yaitu; perbandingan jumlah asesor dan asesi yang tidak ideal, adanya peraturan tentang jumlah asesi yang dapat berpartisipasi dalam proses kredensial, banyak perawat yang bekerja tidak sesuai dengan kompetensinya akibat dampak lamanya waktu tunggu proses kredensial, kurangnya motivasi perawat klinis dalam mengikuti proses kredensial, belum diterbitkannya SK preseptor, belum adanya insentif untuk preseptor, belum dirumuskannya kenaikan jasa perkenaikan jenjang karir, dan proses Internship belum dilaksanakan dalam proses kredensial.
\end{abstract}

Kata Kunci : Jenjang Karir, Perawat Kliniis

\section{Introduction}

Era globalisasi dan terbukanya pasar bebas berakibat pada tingginya kompetisi dalam memberikan pelayanan kesehatan yang menuntut peningkatan kualitas serta profesionalisme sumber daya manusia kesehatan termasuk staf keperawatan (Afidah and Sulisno, 2013). Salah satu upaya rumah sakit dalam menjalankan tugas dan tanggung jawaab untuk menjaga kenyamanan pasien adalah dengan menjaga standar dan kompetensi para staf yang akan berhadapan langsung dengan para pasien di rumah sakit. Pasien perlu dijamin mendapat layanan

Received: 29 September 2020, Accepted : October 2020 - Jurnal Photon Vol.11 No.1

DOI : https://doi.org/10.37859/jp.v17i7.2166

РнОтON is licensed under a Creative Commons Attribution-ShareAlike 4.0 International License 
http://ejurnal.umri.ac.id/index.php/photon

kesehatan yang aman seingga dibutuhkan sistem untuk menjamin akuntabilitas tenaga kesehatan di institusi kesehatan (Susilo, 2013).

Penyelenggaraan pelayanan keperawatan di rumah sakit ditentukan oleh tiga komponen utama yaitu jenis pelayanan keperawatan yang diberikan, sumber daya manusia tenaga keperawatan sebagai tenaga keperawatan memiliki tanggung jawab dan tanggung gugat sesuai kewenangan dalam memberikan asuhan keperawatan kepada klien dan keluarganya.Diperlukan tenaga keperawatan yang kompeten, mampu berfikir kritis, selalu berkembang serta memiliki etika profesi sehingga pelayanan keperawatan dapat diberikan dengan baik, berkualitas dan aman bagi klien dan keluarganya.Kesulitan pelayanan keperawatan sangat tergantung pada perkembangan ilmu pengetahuan dan teknologi, konsumen yang terdidik, perubahan demografi, kompleksitas penyakit, peningkatan biaya kesehatan, dampak kebijakan kesehatan dengan diterapkannya legislasi keperawatan serta kebutuhan pada praktik kolaborasi.Hal ini digambarkan dengan berbagai kondisi seperti tidak jelasnya uraian tugas dan cenderung melakukan tugas rutin, selalu mengalami konflik dan frustasi karena berbagai masalah etik dan disiplin tidak diselesaikan dengan baik, jarang dilakukan pembinaan etika profesi (Sumijatun, 2017).

Pengembangan karir professional perawat dalam bentuk jenjang karir merupakan sistem untuk meningkatkan kinerja dan profesionalisme, sesuai dengan bidang pekerjaan melalui peningkatan kompetensi yang menghasilkan kinerja profesional.Jenjang karir mempunyai makna tingkatan kompetensi untuk melaksanakan asuhan keperawatan yang akuntabel dan etis sesuai batas kewenangan.Adanya jenjang karir perawat dapat meningkatkan pelayanan profesional perawat. Program jenjang karir perawat dirancang untuk menginspirasi dan menghargai keunggulan klinis yag dimiliki. Pengembangan karir perawat dalam konteks penghargaan dapat berupa penghargaan level kompetensi dan kewenangan yang lebih tinggi juga diikuti dengan penghargaan material yang memperhatikan tingkatan level karir dari setiap jenjang karir professional. Perawat profesional diharapkan mampu berfikir rasional, mengakomodasi kondisi lingkungan, mengenal diri sendiri, belajar dari pengalaman dan mempunyai aktualisasi diri sehingga dapat meningkatkan jenjang karir profesinya (Budiono \& Pertami, 2015).

Kredensial merupakan elemen kunci dalam menurunkan resiko litigasi (gugatan hukum di pengadilan) terhadap rumah sakit dan tenaga keperawatan yang bekerja didalamnya. Proses kredensial yang efektif dapat menurunkan resiko adverse events pada pasien dengan meminimalkan kesalahan tindakan yang diberikan oleh tenaga keperawatan tertentu yang memegang kewenangan klinis tertentu dirumah sakit tersebut. Dalam pelaksanaannya ternyata tidak mudah menerapkan kredensial melalui komite keperawatan. Banyak konsuekensi yang harus ditanggung mulai dari sumber daya keperawatan sebagai asesor internal, anggaran yang harus dialokasikan dan sarana prasarana yang mendukung untuk menjamin kelancaran proses kredensial tersebut (Banks and Bailey, 2010).

Saat ini, semangat rumah sakit di Indonesia melakukan kredensial keperawatan melalui komite keperawatan dipengaruhi oleh penilaian standar akreditasi rumah sakit oleh KARS atau JCI. Hal ini seharusnya bersinergi dan saling menguatkan namun pada kenyataannya karena tuntutan rumah sakit yang ingin segera dilakukan penilaian sehingga proses kredensial menjadi kurang bermakna dan cenderung sebatas formalitas(Sahrudin \& Hariyati, 2014). Perawat yang dinyatakan kompeten oleh komite keperawatan dan mendapatkan surat penugasan klinis oleh direktur akan mendapatkan reward, sedangkan perawat yang tidak mengalami peningkatan jenjang karir dalam kurun waktu tertentu akan mendapatkan punishment(Kementerian Kesehatan, 2017).

Sedangkan di lingkungan RSUD Kota Dumai Sendiri terdapat sekitar 322 perawat klinis.Setelah dilakukan wawancara dengan beberapa asesor keperawatan, jenjang karir perawat klinis yang ada di RSUD Kota Dumai cenderung belum mengalami peningkatan dari perawat klinis I ke perawat klinis II. Padahal pihak manajemen RSUD sudah cukup memfasilitasi komite dan bidang keperawatan untuk melakukan proses peningkatan jenjang karir perawat klinis yang memang menjadi salah satu item penting dalam penilaian akreditasi rumah sakit ini.

Seharusnya dengan adanya regulasi pemetaan bagi perawat klinis yang sudah lama bekerja di rumah sakit bisa menjadi sebuah percepatan dalam meningkatkan jenjang karir perawat klinis

Received: 29 September 2020, Accepted : October 2020 - Jurnal Photon Vol.11 No.1

DOI : https://doi.org/10.37859/jp.v17i7.2166

PHOTON is licensed under a Creative Commons Attribution-ShareAlike 4.0 International License 
yang ada di RSUD Kota Dumai.Namun saat ini hasil pemetaan tersebut belum mendapatkan hasil yang signifikan untuk mendukung pengembangan jenjang karir perawat klinis yang ada di RSUD Kota Dumai. Karena setiap level jenjang karir perawat klinis memiliki kompetensi yang berbeda sesuai dengan amanat Permenkes Republik Indonesia tersebut. Dan tentu saja setiap shift kerja memiliki level jenjang karir perawat yang heterogen, jika ada delegasi tindakan dari shift pagi ke shift sore tentu harus dengan perawat yang memiliki jenjang karir sama levelnya dengan yang memberikan delegasi tersebut, hal ini tentu saja untuk meningkatkan mutu pelayanan keperawatan dan melindungi perawat dari hal-hal yang tidak diinginkan. Jenjang karir perawat klinis memilah kompetensi perawat kedalam lima level, setiap level memiliki rincian kewenangan klinis yang berbeda, dan tentu saja semakin tinggi jenjang karir perawat klinis semakin besar remunerasi yang didapat oleh perawat klinis tersebut, karena semakin besar tanggung jawab semakin besar resiko yang dan beban kerja yang akan dihadapi

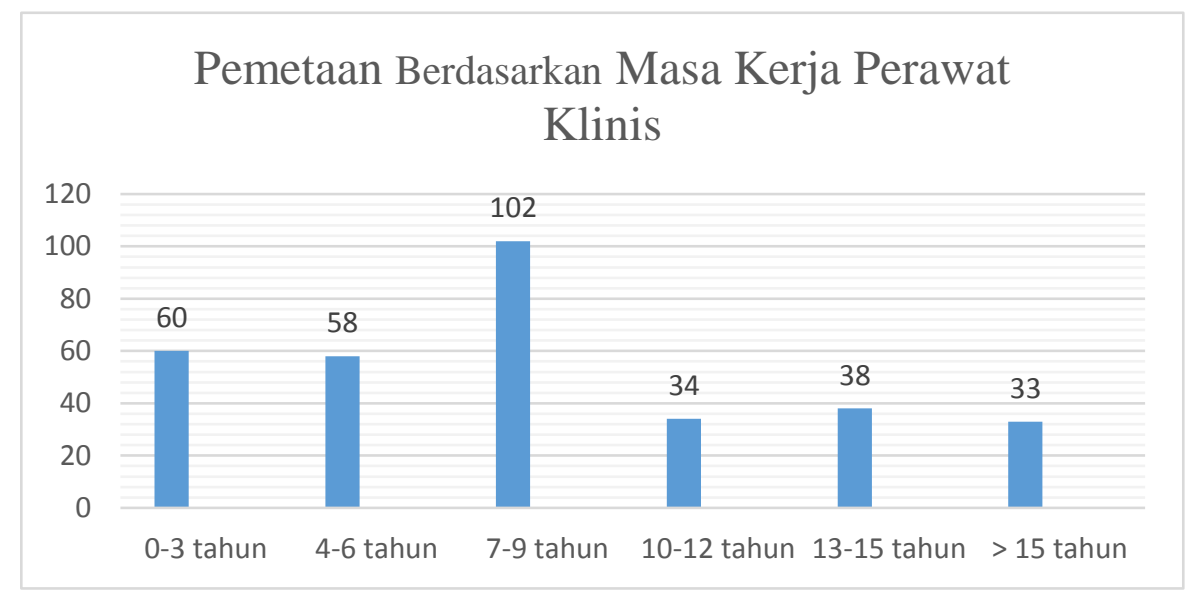

Gambar 1. Pemetaan Berdasarkan Masa Kerja Perawat Klinis Tahun 2017 Sumber : (Keperawatan, 2017b)

Pelaksanaan kredensial keperawatan yang di aplikasikan di Rumah Sakit Umum Daerah Kota Dumai sudah dirumuskan didalam revisi Peraturan Direktur no 10.A tahun 2017, yaitu Peraturan Internal Staf Keperawatan (Nursing Staff By Laws) yang terdapat paa bab IV mengenai rincian jenjang karir perawat klinis (RSUD Kota Dumai, 2017). Sedangkan prosedur tetap kredensial keperawatan langkah demi langkahnya di bahas pada buku putih keperawatan yang juga membahas kelengkapan kredensial dan rincian kewenangan klinis yang akan direkomendasikan oleh komite keperawatan kepada asesi keperawatan yang kompeten dan akan diberikan penugasan klinis oleh Direktur Rumah Sakit (Komite Keperawatan RSUD Kota Dumai, 2015).

Received: 29 September 2020, Accepted : October 2020 - Jurnal Photon Vol.11 No.1

DOI : https://doi.org/10.37859/jp.v17i1.2166

PHOTON is licensed under a Creative Commons Attribution-ShareAlike 4.0 International License 
Kebutuhan ideal jenjang karir perawat klinis yang ada di RSUD Kota Dumai sesuai dengan standar kompetensi perawat klinis di tiap levelnya, kemudian dikombinasikan dengan jumlah shift kerja perawat klinis, jumlah ruangan, jumlah tempat tidur dan jumlah tenaga perawat klinis itu sendiri, dan tentunya tidak mengesampingkan proses pemetaan, kemudian dilihat dari model pemberian pelayanan asuhan keperawatan, dapat disajikan oleh peneliti dalam diagram berikut;

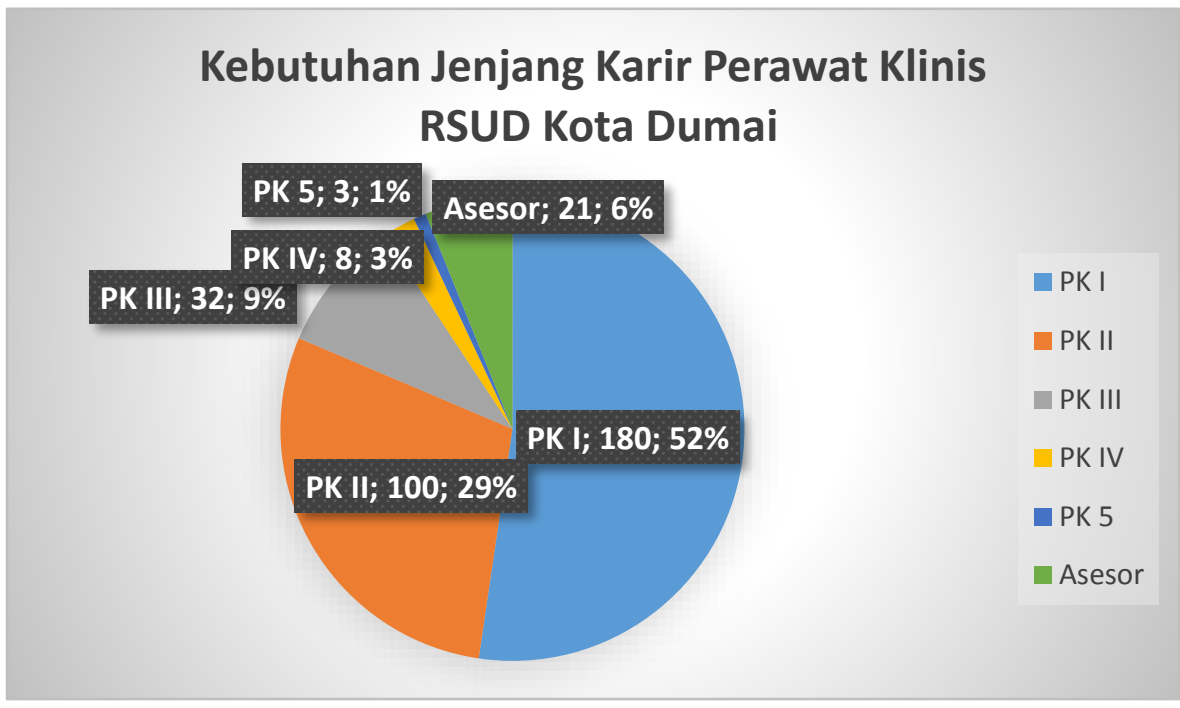

Gambar 2. Kebutuhan Jenjang Karir Perawat Klinis RSUD Kota Dumai Tahun 2018 Sumber ; (Keperawatan, 2017a)

Proyeksi kebutuhan jenjang karir perawat klinis tersebut merupakan kebutuhan minimal yang diperlukan rumah sakit umum daerah Kota Dumai untuk tetap menjaga upaya kesehatan dalam bentuk pelayanan keperawatan yang prima, karena setiap manusia berhak atas pelayanan kesehatan yang aman dan bermutu. Pemerintah bertanggung jawab merencanakan, mengatur, menyelenggarakan, membina, dan mengawasi penyelenggaraan upaya kesehatan yang merata dan terjangkau oleh masyarakat. Pembangunan kesehatan memang diarahkan untuk meningkatkan akses dan mutu pelayanan kesehatan (Republik Indonesia, 2009). Regulasi Jenjang karir perawat klinis selain untuk meningkatkan mutu perawat dan pelayanan keperawatan juga untuk memberi perlindungan dan kepastian hukum kepada perawat dan klien yang merupakan salah satu upaya meningkatkan derajat kesehatan bangsa (Republik Indonesia, 2014).

\section{The Methods}

Penelitian ini termasuk dalam jenis penelitian deskriptif dengan paradigma kualitatif.Lokasi penelitian ini bertempat di Rumah Sakit Umum Daerah (RSUD) Kota Dumai.Informan dalam penelitian ini diambil secara purposivesampling untuk mengetahui informasi sesuai tujuan penelitian yakni informan yang dapat memberikan informasi tentang permasalahan yang diteliti. Penentuan banyaknya informan pada penelitian ini berdasakarkan asas kesesuaian (appropraites) dan kecukupan (adequency).Kecukupan data diukur sendiri oleh peneliti, apabila tidak ada lagi variasi jawaban yang cukup menonjol antara satu sumber data dengan sumber data yang lain dan sudah memenuhi saturasi/kejenuhan, maka peneliti berhenti mencari data/informan (Lapau, 2015).

Received: 29 September 2020, Accepted : October 2020 - Jurnal Photon Vol.11 No.1

DOI : https://doi.org/10.37859/jp.v17i7.2166

PHOTON is licensed under a Creative Commons Attribution-ShareAlike 4.0 International License 
Photon

Jurnal Sains dan Kesehatan

E-15SN : 2579-5953 P-15SN : 2087-393X

http://ejurnal.umri.ac.id/index.php/photon

Informan dalam penelitian ini adalah sebagai berikut

Tabel 1. Data Informan Utama di Rumah Sakit Umum Daerah Kota Dumai Tahun 2018

\begin{tabular}{ccccccc}
\hline No & Informan & $\begin{array}{c}\text { Usia } \\
\text { Tahun }\end{array}$ & $\begin{array}{c}\text { Kenis } \\
\text { Kelamin }\end{array}$ & Pendidikan terakhir & Jabatan & $\begin{array}{c}\text { Lama } \\
\text { Bekerja }\end{array}$ \\
\hline $\mathbf{1}$ & Informan 1 & $\mathbf{3 9}$ & $\mathbf{L}$ & S1 Keperawatan & Ketua Asesor & 20 Tahun \\
\hline $\mathbf{2}$ & Informan 2 & $\mathbf{4 1}$ & $\mathbf{L}$ & S1 Keperawatan & $\begin{array}{c}\text { Ketua Komite } \\
\text { Keperawatan }\end{array}$ & 20 Tahun \\
\hline $\mathbf{3}$ & Informan 3 & $\mathbf{4 1}$ & $\mathbf{L}$ & S1 Keperawatan & Asesor & 20 Tahun \\
\hline $\mathbf{4}$ & Informan 4 & $\mathbf{3 9}$ & $\mathbf{P}$ & $\begin{array}{c}\text { S2 Ilmu } \\
\text { Pemerintahan }\end{array}$ & Asesor & 20 Tahun \\
\hline $\mathbf{5}$ & Informan 5 & $\mathbf{4 0}$ & $\mathbf{L}$ & DIII Keperawatan & $\begin{array}{c}\text { Kepala } \\
\text { Ruangan }\end{array}$ & 20 Tahun \\
\hline $\mathbf{6}$ & Informan 6 & $\mathbf{3 4}$ & $\mathbf{L}$ & SI Keperawatan & Asesi & 12 Tahun \\
\hline $\mathbf{7}$ & Informan 7 & $\mathbf{3 8}$ & $\mathbf{P}$ & DIII Keperawatan & $\begin{array}{c}\text { Kepala } \\
\text { Ruangan }\end{array}$ & 16 Tahun \\
\hline $\mathbf{8}$ & Informan 8 & $\mathbf{4 0}$ & $\mathbf{P}$ & DIV Kebidanan & Asesor & 9 Tahun \\
\hline $\mathbf{9}$ & Informan 9 & $\mathbf{3 6}$ & $\mathbf{P}$ & S1 Keperawatan & Asesor & 9 Tahun \\
\hline $\mathbf{1 0}$ & Informan 10 & $\mathbf{4 2}$ & $\mathbf{P}$ & DIII Keperawatan & $\begin{array}{c}\text { Kepala } \\
\text { Ruangan }\end{array}$ & 20 Tahun \\
\hline $\mathbf{1 1}$ & Informan 11 & $\mathbf{4 0}$ & $\mathbf{L}$ & DIII Keperawatan & Asesi & 11 Tahun \\
\hline $\mathbf{1 2}$ & Informan 12 & $\mathbf{3 1}$ & $\mathbf{L}$ & DIII Keperawatan & Asesi & 6 Tahun \\
\hline $\mathbf{1 3}$ & Informan 13 & $\mathbf{3 3}$ & $\mathbf{L}$ & SI Keperawatan & $\begin{array}{c}\text { Kuangan } \\
\text { 8 Tahun }\end{array}$ \\
\hline
\end{tabular}

Tabel 2. Data Informan Pendukung di Rumah Sakit Umum Daerah Kota Dumai Tahun 2018

\begin{tabular}{|c|c|c|c|c|c|c|}
\hline No & Informan & $\begin{array}{c}\text { Usia } \\
\text { (Tahun) }\end{array}$ & $\begin{array}{c}\text { Jenis } \\
\text { Kelamin }\end{array}$ & $\begin{array}{c}\text { Pendidikan } \\
\text { terakhir }\end{array}$ & Jabatan & $\begin{array}{c}\text { Lama } \\
\text { Bekerja }\end{array}$ \\
\hline 1 & Informan 1 & 48 & $\mathbf{L}$ & S1 Kedokteran & Direktur & 17 Tahun \\
\hline 2 & Informan 2 & 48 & $\mathbf{P}$ & $\begin{array}{c}\text { S2 Kesehatan } \\
\text { Masyarakat }\end{array}$ & $\begin{array}{c}\text { Kabid } \\
\text { Keperawatan }\end{array}$ & 24 Tahun \\
\hline 3 & Informan 3 & 33 & $\mathbf{P}$ & $\begin{array}{l}\text { S2 Kesehatan } \\
\text { Masyarakat }\end{array}$ & $\begin{array}{c}\text { Kasie Etika } \\
\text { mutu } \\
\text { Keperawatan }\end{array}$ & 10 Tahun \\
\hline 4 & Informan 4 & 41 & $\mathbf{L}$ & S1 Keperawatan & Kasie Program & 20 Tahun \\
\hline
\end{tabular}

Penelitian ini telah ditelaah oleh Komisi Etik Penelitian Kesehatan STIKes Hang Tuah Pekanbaru dan telah melalui prosedur Kaji Etik dan dinyatakan layak untuk dilaksanakan dengan nomor: 031/KEPK/STIKes-HTP/VII/2018, tanggal 3 Agustus 2018

Received: 29 September 2020, Accepted : October 2020 - Jurnal Photon Vol.11 No.1

DOI : https://doi.org/10.37859/jp.v17i1.2166

PHOTON is licensed under a Creative Commons Attribution-ShareAlike 4.0 International License 


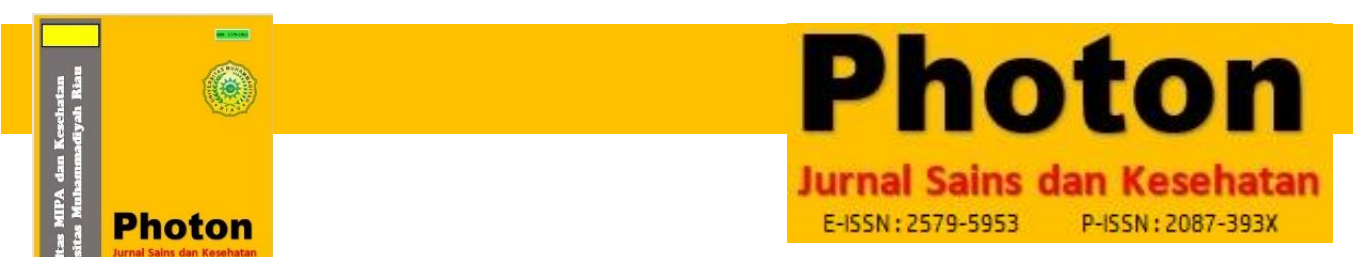

http://ejurnal.umri.ac.id/index.php/photon

\section{Result and Discussion}

\section{Input}

\section{a. Sumber Daya Manusia}

Hasil wawancara mendalam membuktikan bahwa antara asesor dan asesi itu tidak seimbang, dimana jumlah asesor 7 orang, sedangkan yang akan dilakukan asesmen berjumlah 322 orang, sehingga perbandingannya menjadi 1: 46 .

Berdasarkan wawancara yang dilakukan kepada informan ditemukan data bahwa RSUD Kota Dumai melimpahkan proses preseptorship atau mentorship kepada kepala ruangan dan belum dibuat surat keputusannya di dalam proses jenjang karir perawat klinis. Berdasarkan Aturan Rumah Sakit 1 asesor hanya boleh menangani 10 asesi setiap tahun, sehingga terjadi perpanjangan waktu penilaian, yang seharusnya bisa selesai dalam waktu setahun, di RSUD Kota Dumai butuh waktu 4 tahun. Berdasarkan hasil wawancara dampak yang terjadi akibat lamanya waktu tunggu adalah perawat bekerja tidak sesuai dengan kompetensinya.Berdasarkan hasil wawancara kepada informan ditemukan data tentang motivasi perawat klinis yang mengikuti proses kredensial. Sehingga dapat disimpulkan SDM yang mendukung terlaksananya proses jenjang karir masih kurang dan berdampak pada administrasi ketenagaan perawat klinis dirumah sakit. Ini sesuai dengan dokumen data ketenagaan keperawatan RSUD Kota Dumai per Desember Tahun 2017.

b. Biaya

Berdasarkan hasil wawancara mendalam untuk mendukung proses jenjang karir itu dibutuhkan biaya berupa honor, baik itu honor asesor, honor perseptor maupun peningkatan jasa per kenaikan jenjang karir. Berdasarkan hasil wawancara mendalam untuk mendukung proses jenjang karir itu dibutuhkan biaya makan dan minum panitia serta penggandaan format. Selain biaya yang sudah disebutkan diatas berdasarkan hasil wawancara, biaya pelatihan juga perlu dianggarkan, baik untuk sertifikasi asesor, maupun resertifikasi. Sehingga dapat disimpulkan pada variabel biaya ditemukan tidak ada anggaran untuk mentor atau preseptor dan kenaikan jasa setiap peningakatan jenjang karir perawat klinis ini akan menjadi suatu hambatan kelancaran terlaksananya proses jenjang karir perawat klinis di RSUD Kota Dumai. Ini sesuai dengan RKA Bidang Keperawatan Tentang Uji Kompetensi Tenaga Keperwatan Tahun 2017.

\section{Process}

a. Internship

Berdasarkan hasil wawancara mendalam untuk mendukung proses jenjang karir itu harus dilakukan proses internship, pada variabel ini peneliti menemukan data tentang waktu yang dibutuhkan untuk proses internship diberikan dan apa saja yang didapat dari proses internship tersebut. Berdasarkan hasil wawancara Ada 4 ruangan yang harus dijalani perawat klinis selama proses internship. Berdasarkan hasil wawancara mendalam untuk mendukung proses jenjang karir itu perlu dilakukan proses mentorship dan preseptorship, namun tidak dilakukan pada proses internship di RSUD Kota Dumai. Sehingga dapat disimpulkan pada proses internship tidak diterapkan pelaksanaan perseptorship atau mentorship, ini akan menjadi hambatan kelancaran terlaksananya proses jenjang karir perawat klinis di RSUD Kota Dumai. Hal ni Sesuai dengan Dokumen Standar Operasional Orientasi Perawat Klinis Baru RSUD Kota Dumai dan PMK No. 40 Tahun 2017 tentang Jenjang Karir Perawat Klinis.

Setelah selesai melakukan penelitian, peneliti mencoba untuk membuat sebuah proyeksi peningkatan jenjang karir perawat klinis dengan kurun waktu lima tahun kedepan, disesuaikan dengan kondisi jenjang karir perawat klinis yang ada pada saat ini. Hingga melakukan percepatan agar pengembangan jenjang karir perawat klinis yang ada bisa naik dengan progres yang signifikan.Namun dalam penyusunan proyeksi ini peneliti tetap mempertimbangkan dan mengacu kepada Rencana Strategis Rumah Sakit Umum Daerah Kota Dumai Tahun 2016-2021 dan pada proyeksi ini peneliti tidak memperhatikan tingkat inflasi per tahunnya.

1) Tahun 2019

Pada akhir tahun 2018 RSUD Kota Dumai perlu menambah jumlah asesor sekitar 5 orang, sehingga total asesor yang ada pada saat itu berjumlah 12 orang, dan dapat melakukan

Received: 29 September 2020, Accepted : October 2020 - Jurnal Photon Vol.11 No.1

DOI : https://doi.org/10.37859/jp.v17i7.2166

PHOTON is licensed under a Creative Commons Attribution-ShareAlike 4.0 International License 
asesmen kepada 180 orang perawat klinis untuk menuju ke PK II, dan karena setiap tahun ada perawat klinis baru yang masuk ke RSUD Kota Dumai maka diperlukan preseptor untuk membimbing perawat klinis yang masih dalam proses internship.

2) Tahun 2020

Pada akhir tahun 2019 untuk mempersiapkan asesmen PK III RSUD Kota Dumai perlu melakukan penambahan jumlah asesor untuk mempersiapkan asesmen PK III itu sendiri, asesmen PK I menuju PK II dan asesmen pra klinis menuju PK I. Pada tahun ini pihak manajemen RSUD Kota Dumai perlu melakukan penambahan preseptor klinis karena beberapa perawat klinis baru masuk untuk meningkatkan kinerja pelayanan keperawatan RSUD Kota Dumai, dan perawat yang baru naik ke level PK yang lebih tinggi juga harus diberikan bimbingan dalam melakukan tindakan keperawatan sesuai dengan level PK yang baru.

3) Tahun 2021

Pada akhir tahun 2020, pihak manajemen RSUD Kota Dumai sudah perlu mempersiapkan melakukan Exhouse Assesment untuk meningkatkan level perawat klinis hingga ke PK IV dan PK V, dengan cara mengirim calon asesi melaksanakan proses kredensial di Rumah Sakit yang level perawat klinis nya sudah lengkap, biasanya dilakukan di Rumah Sakit Umum Rujukan Provinsi atau Rumah Sakit Umum Pusat. RSUD Kota Dumai melakukan Exhaouse Assesment, untuk melakukan percepatan pengembangan jenjang karir perawat klinis yang ada di RSUD Kota Dumai, sedangkan asesor keperawatan internal masih dalam kegiatan kredensial dilevel PK I-III, dan pihak manajemen RSUD Kota Dumai tetap harus menambah jumlah asesor dan preseptor karena tiap tahunnya perawat klinis bertambah sesuai dengan jumlah tempat tidur.

4) Tahun 2022

Pada akhir tahun 2021 RSUD Kota Dumai tetap melakukan Exhouse assesment untuk PK IV dan PK V namun tetap memperhatikan kualifikasi pendidikan, pelatihan yang pernah diikuti dan pengalaman kerja yang telah memenuhi syarat untuk level jenjang karir PK IV dan PK V. pada tahun ini RSUD Kota Dumai perlu untuk mempersiapkan asesmen PK IV di lingkungan RSUD sendiri, karena beberapa perawat klinis sudah mendapatkan sertifikasi PK IV dan V pada tahun sebelumnya dengan Exhouse training di Rumah Sakit rujukan Provinsi ataupun Rumah Sakit Umum Pusat.

5) Tahun 2023

Pada tahun ini RSUD Kota Dumai diharapkan dapat melakukan asesmen kompetensi perawat klinis level I-V dilingkungan Internal RSUD Kota Dumai karena pada tahun sebelumnya sudah ada 8 orang perawat klinis level IV dan 4 orang perawat klinis level V. jadi mulai tahun 2023 dan untuk kedepannya RSUD Kota Dumai sudah dapat melakukan kredensial untuk perawat klinis di lingkungan RSUD Kota Dumai tanpa mengirim asesi ke rumah sakit lain untuk dilakukan Exhouse assessment.Namun seiring berjalannya waktu dengan pengembangan pelayanan RSUD Kota Dumai dan penambahan jumlah perawat klinis yang sesuai dengan jumlah tempat tidur, maka jumlah asesor dan preseptor perlu menyesuaikan dengan jumlah perawat klinis yang ada.

Received: 29 September 2020, Accepted : October 2020 - Jurnal Photon Vol.11 No.1 
Tabel 3. Proyeksi Perangkat Jenjang Karir dalam Jangka Lima Tahun Kedepan

\begin{tabular}{|c|c|c|c|c|c|c|c|c|c|}
\hline No & Jenjang Karir & Jumlah Asesor & Kondisi Sekarang & 2019 & 2020 & 2021 & 2022 & 2023 & Biaya \\
\hline 1 & Pra PK & & - & 12 & 12 & 12 & 12 & 12 & Rp. 75.000.000,00 \\
\hline 2 & PK I & 5 & 322 & 161 & 12 & 24 & 24 & 24 & Rp. $16.800 .000,00$ \\
\hline 3 & PK II & 12 & - & 161 & 310 & 297 & 148 & 161 & Rp. $121.100 .000,00$ \\
\hline 4 & PK III & 5 & - & - & 12 & 22 & 161 & 161 & Rp. $56.350 .000,00$ \\
\hline 5 & PK IV & 3 & - & - & - & 6 & 8 & 13 & Rp. 84.500.000,00 \\
\hline 6 & PK V & & - & - & - & 3 & 4 & 5 & Rp. $32.500 .000,00$ \\
\hline 7 & Asesor & & 7 & 12 & 15 & 18 & 20 & 25 & Rp. $162.500 .000,00$ \\
\hline 8 & Preseptor & 20 & - & 4 & 8 & 12 & 16 & 20 & Rp. 64.400.000,00 \\
\hline & Integrasi IT & - & - & - & \multicolumn{4}{|c|}{ Teknologi Informasi Sistem Terintegrasi } & \\
\hline & Jumlah & 25 & 322 & 334 & 346 & 340 & 370 & 376 & Rp. 583.900.000,00 \\
\hline
\end{tabular}

Received: 29 September 2020, Accepted : October 2020 - Jurnal Photon Vol.11 No.1

DOI : https://doi.org/10.37859/jp.v17i7.2166

PHOTON is licensed under a Creative Commons Attribution-ShareAlike 4.0 International License 


\section{Conclusion}

Dalam perjalanan proses jenjang karir perawat klinis, peran asesor preseptor, komite keperawatan dan Bidang keperawatan terbilang cukp besar, dan harus didukung oleh pihak pemangku kebijakan lainnya di rumah sakit yang memang ingin meningkatkan mutu pelayanan tenaga keperawatan yang merupakan sumber daya manusia terbesar yang ada di sebuah rumah sakit. Dalam proses jenjang karir harus memperhatikan aspek sumber daya manusia, biaya dan proses internship yang berjalan, dan perkembangannya juga harus selalu dipantau dengan kemajuan teknologi yang ada sekarang integrasi sistem informasi manajemen rumah sakit merupakan salah satunya.

\section{References}

Afidah, E. N. and Sulisno, M. (2013) 'gambaran pelaksanaan peran advokat perawat di rumah sakit negeri di kabupaten semarang', 1(2), pp. 124-130.

Banks, Z. M. and Bailey, J. H. (2010) 'Career Motivation in Newly Licensed Registered Nurses: What Makes Them Remain Career Motivation in Newly Licensed Registered Nurses : What Makes', 15(6), pp. 1489-1503.

budiono \& Pertami, S. B. (2015) Konsep Dasar Keperawatan. edisi 1. Edited by R. Parman, Suryani \& Damayanti. Jakarta: Bumi Medika.

Kementerian Kesehatan (2017) Peraturan Menteri Kesehatan Nomor 40 tahun 2017 tentang Pengembangan Jenjang Karir Perawat Klinis. Jakarta.

Keperawatan, B. (2017a) Analisis Ketenagaan Keperawatan RSUD Kota Dumai. Dumai.

Keperawatan, B. (2017b) Laporan Evaluasi bidang Keperawatan RSUD Kota Dumai. Dumai.

Komite Keperawatan RSUD Kota Dumai (2015) White Paper Keperawatan. Dumai.

Lapau, B. (2015) Metode Penelitian Kesehatan: Metode Ilmiah Penulisan Skripsi, Tesis dan Disertasi. edisi ke 3. Jakarta: Yayasan Pustaka Obor Indonesia.

Republik Indonesia (2009) 'Kesehatan'.

Republik Indonesia (2014) Undang-undang Republik Indonesia Nomor 38 Tahun 2014 tentang Keperawatan. Jakarta.

RSUD Kota Dumai (2017) 'Peraturan Direktur No. 010.A'.

Sahrudin \& Hariyati (2014) 'Persepsi Tentang Peningkatan Jenjng Karir Perawat Rumah Sakit Cilegon', pp. 1-8.

Sumijatun (2017) Konsep Dasar Menuju Keperawatan Profesional. edisi revi. Edited by Maftuhin Ari. Jakarta: Trans Info Media.

Susilo, A. P. (2013) 'Simulasi Penetapan Kewenangan Klinik Efektif Sebagai Alat Sosialisasi Sistem Kredensial Profesi Keperawatan Pendahuluan', 16(3), pp. 190196.

Received: 29 September 2020, Accepted : October 2020 - Jurnal Photon Vol.11 No.1

DOI : https://doi.org/10.37859/jp.v77i1.2166

PHOTON is licensed under a Creative Commons Attribution-ShareAlike 4.0 International 